\title{
Participation of People Living with HIV/AIDS in Community-Based AIDS Coping
}

\author{
Argyo Demartoto ${ }^{1}$, Siti Zunariyah ${ }^{2}$ \\ Department of Sociology \\ Universitas Sebelas Maret \\ Surakarta, Indonesia \\ ${ }^{1}$ argyodemartoto_fisip@staff.uns.ac.id, \\ ${ }^{2}$ zunariyah@staff.uns.ac.id
}

\author{
Bhisma Murti \\ Department of Public Health \\ Universitas Sebelas Maret \\ Surakarta, Indonesia \\ bhisma.murti@staff.uns.ac.id
}

\begin{abstract}
Stigma and negative treatment against People Living with HIV/AIDS or PLWHAs becomes a serious problem in Indonesia, so that they become introverted. This research aimed to analyze the participation of PLWHAs in communitybased AIDS coping. This qualitative research with exploratory approach was taken place in Surakarta Indonesia. PLWHAs affiliated with Solo Plus Peer Support Group became main informants selected purposively. Data was collected through observation, in-depth interview, and documentation, and then was analyzed using Parsons' action theory. Data validation was conducted using source and method triangulations. The result of research showed that PLWHAs with open status tend to participate actively in promotive, preventive, curative, and rehabilitative activities to cope with AIDS, including communicating, informing, and educating the community earlier about HIV/AIDS and recommending them to be loyal to their partner, not using injected drug, and respecting PLWHAs. PLWHAs' right to freedom of expression has not been fulfilled optimally because there is negative label and movement space limitation by community. Education about HIV/AIDS and PLWHAs' rights should be improved among the public.
\end{abstract}

Keywords-participation; PLWHA; right to freedom of expression

\section{INTRODUCTION}

AIDS epidemics becomes a global health challenge, as the cumulative number of HIV/AIDS cases increases over times; there are 36.7 millions cases up to December 2016. Republic of Indonesia's Health Ministry reports that there are 242.699 cases in Indonesia, 18.038 in Central Java, and 2.428 in Surakarta up to March 2017. People live with HIV/AIDS (PLWHA) get stigma and discriminative treatment from family, community and healthcare service officer [1-4]. Meanwhile, they are entitled to receive medical service and treatment, have right to job, education, politics and participation in AIDS coping [5-8].

AIDS coping program in Indonesia refers to, zero new infection, zero AIDS-related death, and zero discrimination paradigms. Some methods are used to prevent the transmission of HIV/AIDS in the group with high risk of being infected with HIV and general society, and Prevention of Mother to Child Transmission (PMTCT). Care Support and Treatment (CST) includes healthcare service reinforcement and development, support, opportunistic infection treatment and antiretroviral therapy, and education and training for PLWHA. CST is intended to reduce sickness and inpatient rate, and AIDSinduced death rate, and to improve life quality of PLWHA. The effect is mitigated through psychosocio-economic support and conducive environment establishment [9-11].

AIDS management involves entire society including Peer Support Group (PSG) with which PLWHA are affiliated, partners, and People affected by HIV/AIDS (PABHA). Central Java is a province with the largest number of PSGs, 43 groups, one of which is Solo Plus Surakarta. PSG is really beneficial, as PLWHA cannot deal with their health problem alone, so that they can be opened, share information and even get psychosocial support. In addition, it can be a vehicle for activists who want to participate in fulfilling the PLWHA's interest [12].

Participative development growing in the society is affected by age, sex, education, occupation, income, and length of staying factors [13, 14]. As a social action, participation is supported by actor, alternative method, tool and technique; is confronted with a number of situational conditions that can restrict the action; and is under the control of norm affecting selection, determination and alternative action to achieve the objective $[15,16]$. The classification of participation ladders includes citizen power, tokeinisme, and non participation, while the hierarchy of participation includes spectator, support, engagement, and decision-making [17-19]. Participation is beneficial to successful organization, as it enables the collective decision making, contributes positively and significantly, emphasizes on a two-way communication, practices accountability for collective interest, and follows any changes occurring $[20,21]$. This research aimed to analyze the participation of PLWHAs in community-based AIDS coping.

\section{METHOD}

This research was taken place in Surakarta Indonesia on February-April 2017. Data and information of this qualitative research with exploratory approach included significant subjective perception of Solo Plus PSG's administrators and members and stakeholders related to AIDS coping, such as Managerial Program of Surakarta City's AIDS Coping Commission, PLWHA facilitator, and healthcare service 
officer. Data collection was conducted using observation, indepth interview, and documentation methods, while data validation was carried out using data source triangulation and method. Data analysis was conducted using an interactive model of analysis, encompassing data collection, data reduction, and conclusion drawing [22, 23].

\section{RESULT}

Solo Plus Surakarta was established as the response to the PLWHA and affected family's need for psychosocial support. It aims largely to fight for the equality of right, the opportunity to access healthcare service and support, and the removal of stigma and discrimination against PLWHA. It has 190 members, but only 50 out of them become active members, because of less self-confidence, introversion including among PLWHAs and fear of seeing acquaintance or neighbor likely opening their HIV status to family or others. Some others consider that PSG is useless.

The chairperson of Solo Plus states that some attempts have been taken to improve the capacity of organization and its members by attending various trainings; psychosocial support; monthly routine meeting; session information, for example from psychiatric, herbalist, Voluntary Counseling and Testing (VCT); embracing all PLWHAs in Surakarta in order to be affiliated with the organization and to update database. The Program Manager of Surakarta City's AIDS Coping Commission said that Solo Plus has implemented policy advocacy and made the public aware through audience with government, initiated satellite PSGs establishment in surrounding area to facilitate the local government's support, participated actively in campaign for HIV/AIDS prevention, and given testimony in many events.

A transsexual and a housewife infected with HIV support CST service actively through case management (VCT referral, CST, Local Health Security); CD4 test, Liver and Renal Function Test, PMTCT; Supplementary Food Administration; Facilitation for children with HIV/AIDS and PLWHA at home, in hospital and in penitentiary to support life spirit, opening status and changing their behavior. Solo Plus also develops network and support its members' livelihood sustainability by contacting government, NGO, private; individual or group business capital stimulant grant; establishing cooperation and facilitating life skill training for its members.

Solo Plus's program and activity are design by all members through coordination meeting, budgeting and program achievement. However, in its implementation there are such constraints as limited fund, less optimal government support, discriminative healthcare officer and community and difficulty of dealing with PLWHA lost follow up.

A facilitator of PLWHA argues that PLWHA's participation in PSG is very important as AIDS coping is entirely concentrated on and beneficial to PLWHA or clientcentered. They are not only the object but also the subject, so that they are powerful and understand what occurs in their body and the effect of HIV on their health including treatment with both ARV and opportunistic infection. The powerful patients participate in decision making to begin treatment (medication) based on a comprehensive information. PSG activity also includes disseminating knowledge or information about ARV drug consumption regularity, recalling that many PLWHAs have not complied with consuming ARV thereby increasing their health risk and passing away. As the intensity of PSG meeting increases, PLWHA understand that HIV is not a deadly virus, but it can be controlled with ARV therapy that has been proven medically. Psychically PLWHAs can do any activity just like the normal ones, perform as powerful ones, who are healthy physically and mentally.

A therapist and VCT counselor in Dr. Moewardi hospital says that PLWHA is risky of being infected by any diseases more easily compared with others, but being active in Solo Plus, PLWHAs will be able to deal with the health problem they encounter, as they come to and consult with medical officer vigorously and undertake healing process actively. Empowerment can increase information about health service including patients' right and obligation, and identifying whether or not medical measure received has been appropriate and whether or not they get discriminative treatment or not. Good self-understanding in health context is a certainty that PLWHAs can be committed to themselves not to transmit their disease to others and for the sake of their own health vulnerable to disease attack. The advantage of participating in PSG is that it improves the community's awareness of condition encountered by treating PLWHAs humanely, and resulting in the change through creating public or political voice.

\section{DISCUSSION}

The problem the PLWHAs encounter is not only ever degrading physical condition but also negative label and discrimination form they get from environment. It affects PLWHAs' view on themselves, determining their interpersonal communication because everyone behaves consistently with their self-concept. AIDS coping program attempts to realize three zeroes HIV/AIDS in order to be consistent with the target of Sustainable Development Goals: to ensure healthy lives and to promote well-being for all at all ages. However, to realize it, support from stakeholders including government, nongovernment and community is required. As the member of society, PLWHAs and PABHAs can participate and support PSG's program and activity.

AIDS coping program will be more effective when it involves PLWHA followed with good attitude from partner, family support, and health officer, Local AIDS Coping Commission, control behavior felt and positive intention. At social level, as a result of stigma, the members of society rarely consider destigmatization, the process in which their group value and status improve. Destigmatization is very important as it exerts positive effect on the stigmatized group's health, new culture construction about equality and removing structural stigma and public along the time [12, 24].

Solo Plus as an actor serves to produce, to disseminate, to institutionalize two cultural constructions: relieving any problem and realizing equality in PLWHA case [16]. The change of stigmatization process between PLWHAs who have consumed ARV, for example, needs self management related to ARV. In addition, medical officer's support and intervention 
such as counseling, facilitation and PSG can help PLWHAs reconstruct their more positive alternative identity [6].

The important role of health service officer in reducing stigma is to maintain counseling and to support PLWHA having problem with stigma and status openness. They serve to resist stigma at interpersonal and intrapersonal levels, through daily thinking and action. This process is confirmed with collective identity and solidarity feelings among their partners and fellows PLWHAs [25]. Although affecting self-esteem, PSG serves to help PLWHAs deal with their self stigma, reconstruct problem and positive identity, and improve their wellbeing [2].

PLWHAs' participation in AIDS coping program becomes a capital to improve literacy and intervention intended to fulfill psychosocial need, in order to improve their life quality. It is also associated with decreased mortality and morbidity rates, improved service, and improved life quality of PLWHAs.

\section{CONCLUSION}

PLWHA's right to freedom of expression as civil citizen is reflected on their participation in various activities of PSG. They participate in planning, implementation, result use and evaluation in promotive, preventive, curative, and rehabilitative activities supporting the achievement of three zeroes HIV/AIDS.

\section{REFERENCES}

[1] A.C. Tsai, D.R. Bangsberg, S.M. Kegeles, I.T. Katz, J.E. Haberer, C. Muzoora, E. Kumbakumba, P.W. Hunt, J.N. Martin, and S.D. Weiser, "Internalized stigma, social distance, and disclosure of HIV seropositivity in rural Uganda," Annals of Behavioral Medicine, vol. 46, no. 3, pp/ 285-94, 2013

[2] O.E. Omosanya, O.T. Elegbede, S.M. Agboola, A.O. Isinkaye, and O.A Omopariola, "Effects of stigmatization/discrimination on antiretroviral therapy adherence among HIV-infected patients in a rural tertiary medical center in Nigeria," Journal of the International Association Providers of AIDS Care, vol. 13, no. 3, pp. 260-3, 2014.

[3] V. Paudel and K.P. Baral, "Women living with HIV/AIDS (WLHA), battling stigma, discrimination and denial and the role of support groups as a coping strategy: a review of literature," Reproductive Health, vol. 12 , pp. 53, 2015.

[4] H.A. Gesesew, A.T. Gebremedhin, T.D. Demissie, M.W. Kerrie, M Sudhakar, and L. Mwanri, "Significant association between perceived HIV related stigma and late presentation for HIV/AIDS care in low and middle-income countries: A systematic review and meta-analysis," PloS One, vol. 12, no. 3, pp. e0173928, 2017.

[5] L.O. Gostin and Z. Lazzarini, Human Rights and Public Health in the AIDS Pandemic. Oxford, USA: Oxford University Press, 1997

[6] P.S. Jones, AIDS Treatment and Human Rights in Context. New York, US: Palgrave Macmillan, 2009.
[7] H. Altinay and K. Dervis, Global Civics: Responsibilities and Rights in an Interdependent World. Washington, DC: Brookings Institution Press, 2011.

[8] S. Weinick, Understanding Your Rights in the Information Age. New York: The Rosen Publishing Group, Inc., 2013.

[9] Kementerian Kesehatan Republik Indonesia. Pedoman Nasional Tata Laksana Klinis Infeksi HIV dan Terapi Antiretroviral pada Orang Dewasa. Jakarta: Kementerian Kesehatan Republik Indonesia, 2011.

[10] A. Demartoto, E. IES Gerilyawati, and D.P. Sudibyo, “A Sustainable Comprehensive Service through Greater Involvement of People Living with HIV/AIDS in the HIV/AIDS Management Program in Surakarta City of Indonesia," Asian Social Science, vol. 10, no. 4, pp. 52-66, 2014.

[11] V. Frye, M.Q. Paige, S. Gordon, D. Matthews, G. Musgrave, M Kornegay, E. Greene, J.C. Phelan, B.A. Koblin, and V. TaylorAkutagawa, "Developing a community-level anti-HIV/AIDS stigma and homophobia intervention in New York city: The project CHHANGE model," Evaluation and Program Planning, vol. 63, pp. 45-53, 2017.

[12] M.H. Bateganya, "Impact of Support Groups for People Living With HIV on Clinical Outcomes: A Systematic Review of the Literature,' Journal Acquired Immune Deficiency Syndromes, vol. 68, pp. 368-374, 2015.

[13] J. Midgley, Community Participation, Social Development, and the State. United Kingdom: Routledge: 8-9, 1986.

[14] E.H. Abed, D. Lindsay, and W.A. Hashlamoun, "On Participation Factors for Linear Systems," Automatica, vol. 36, pp. 1489-1496, 2000.

[15] T. Parsons, The Present Status of Structural-Functional Theory in Sociology. In T. Parsons Social Systems and The Evolution of Action Theory. New York: The Free Press, 1975.

[16] T. Parsons, Action Theory and the Human Condition. New York: Free Press, 1978

[17] S.R. Arnstein, "A Ladder of Citizen Participation," Journal of the American Planning, vol. 35, no. 4, pp. 216-224, 1969.

[18] J. Cohen and N.T. Uphoff, "Rural Development Participation: Concept and Measures for Project Design-Implementation and Evaluation," New York: Cornell University Press, 1977.

[19] L. Botes and D. van Rensburg, "Community Participation in Development: Nine Plagues and Twelve Commandments," Community Development Journal, vol. 35, no. 1, pp. 42, 2000.

[20] J. Plummer and J.G. Taylor, Ed., Community Participation in China: Issues and Processes for Capacity Building. London: Earthscan Publications Ltd, 2004.

[21] A.E. Azzi, X. Chryssochoou, B. Klandermans, and B. Simon, Eds. Identity and Participation in Culturally Diverse Societies: A Multidisciplinary Perspective. United Kingdom : Wiley-Blackwell, 2010

[22] C. Becker and R. Fried, Exploratory Data Analysis in Empirical Research: Proceedings of the 25th Annual Conference of the Gesellschaft für Klassifikation e.V., University of Munich, March 1416, 2001. Verlag Berlin Heidelberg: Springer, 2003.

[23] J.W. Creswell, Research Design: Qualitative, Quantitative, and Mixed Methods Approaches, 4thed. London, United Kingdom: Sage Publications Inc., 2013.

[24] M. Clair, "Destigmatization and Health: Cultural Constructions and The Long term Reduction of Stigma," Social Science and Medicine, vol. 165 , pp. 223-232, 2016.

[25] S. Russell, F. Zalwango, S. Namukwaya, J. Katongole, R. Muhumuza R. Nalugya, and J. Seeley, "Antiretroviral therapy and changing patterns of HIV stigmatisation in Entebbe, Uganda," Sociology of Health \& Illness, vol. 38, no. 1, pp. 58-72, 2016 